\title{
SYSTEMIC LUPUS ERYTHEMATOSUS (SLE) IN A MALE PATIENT PREVIOUSLY DIAGNOSED AS ADULT ONSET STILL'S DISEASE: A CASE REPORT
}

\author{
MD. ANWAR SAYED ${ }^{1}$, SUMAN CHOWDHURY²
}

\begin{abstract}
:
Adult-onset Still's disease (AOSD) is a rare clinical entity with unknown etiology, characterized by evanescent rash, arthritis, fever, and other systemic presentation. In this case report, we describe a male patient of 50 years, previously diagnosed as a case of Adult onset still's disease based on Yamaguchi criteria after the exclusion of other potential diagnoses. Later he was admitted into the Medicine department of Chittagong Medical College Hospital where he was found to have serological features of Systemic lupus erythematosus, another very much uncommon autoimmune disorder in male. On several occasion of his past admissions, SLE and RA were excluded meticulously. He initially responded to oral steroids only, recurrence of symptoms led us to work on the underlying etiology further. Coexistence of SLE in a patient with AOSD is not so commonly found. In our case, we notice this interesting phenomenon which was crucial for his management.
\end{abstract}

Keywords: Adult-onset Still's disease, SLE, DMARD, Yamaguchi criteria.

Received: 10 January 2019

Accepted: 11 April 2019

DOI: https://doi.org/10.3329/bjmed.v30i2.41538

\section{Introduction:}

Systemic lupus erythematosus (SLE) is a chronic, occasionally life-threatening, multi-system disorder of autoimmune origin in which organs and cells undergo damage initially mediated by tissue-binding autoantibodies and immune complexes. Ninety percent of patients are women of child-bearing years; people of all genders, ages, and ethnic groups are susceptible. Prevalence of SLE in the United States is 20-150 per 100,000 women depending on race and gender; highest prevalence is in African-American and Afro-Caribbean women, and lowest prevalence is in white men ${ }^{1}$. Adult Onset Still Disease (AOSD) is a rare systemic inflammatory disorder with unknown etiology. The prevalence of AOSD is estimated to be one per 100,000 people ${ }^{2}$. The disease mainly affects young adults and has a bimodal age distribution at 15-25 and 36-46 years of age ${ }^{3}$. The prevalence of SLE is far lower in males than in females, especially after puberty ${ }^{4}$. Additionally, gender may produce different characteristics in the manifestation of $\mathrm{SLE}^{5}$. The etiology of SLE remains unknown and is clearly multifactorial ${ }^{6}$. Coexistence of SLE in a patient with AOSD is not so commonly found. In our case, we notice this interesting phenomenon.

\section{Case Presentation:}

Mr. Jahangir Alam Bahar, a 50 years old Taxi-driver (Figure I), normotensive, non-diabetic, hailing from Sitakundu, Chattogram, was admitted in medicine ward of Chittagong Medical College Hospital with the complaints of Fever for 1 month, multiple joints pain for same duration and rash in different parts of the body for 25 days. He provided similar history of

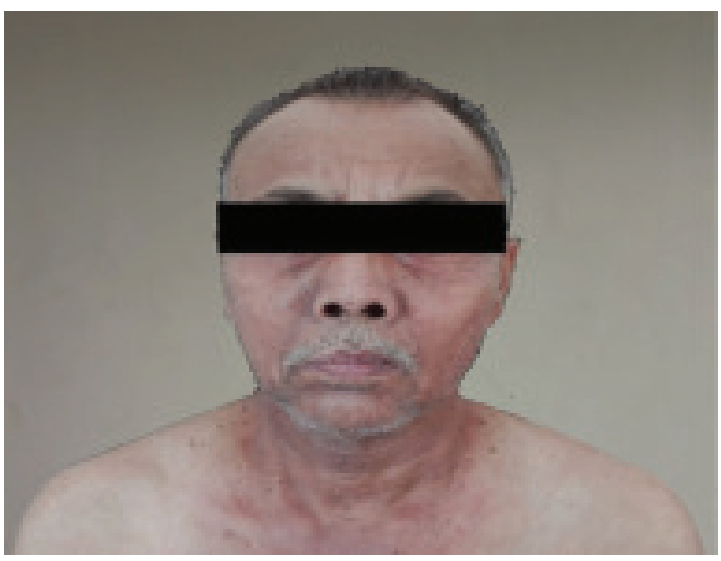

Figure 1: The 50 years old male patient

1. Indoor Medical Officer, Department of Medicine, Chittagong Medical College and Hospital

2. Medical Offier, Colonel hut Urban Dispensary, Chattogram

Address of Correspondence: Dr. Md. Anwar Syed, Indoor Medical Officer, Department of Medicine, Chittagong Medical College and Hospital, E-mail: dr.anwar_cmc@yahoo.com 


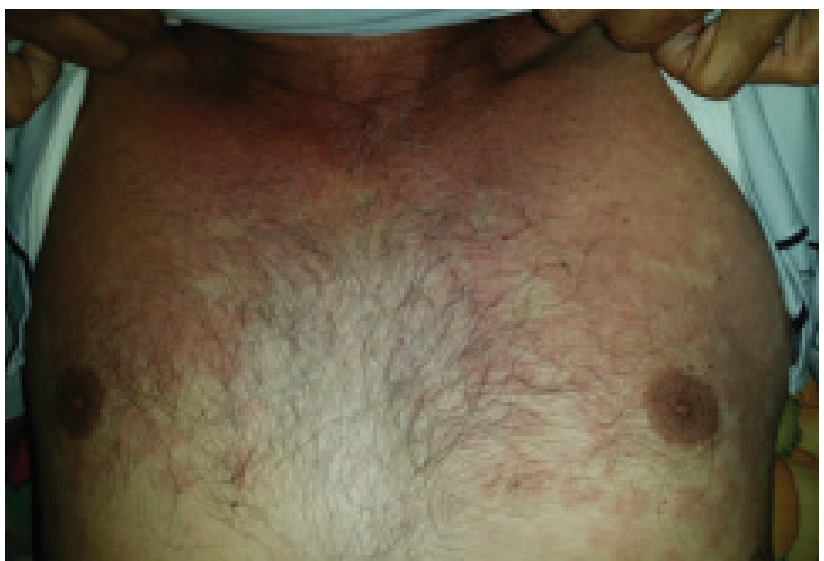

Figure 2A: Blanchable, Non itchy, non palpable pink rashes on chest

recurrent hospitalization in last 5 years. According to patient's statement, he was relatively well 1 month ago. Then he developed high grade fever, continued in nature, associated with generalized body ache, weakness and skin rash but no chills and rigors, evening rise of temperature or night sweats. Highest recorded temperature was $103 \mathrm{~F}$. The intensity of the fever diminished to some extent with antipyretics but did not subside fully.

He developed inflammatory, symmetrical joint pain involving knees, ankles and small joints of hands for last 1 month. Pain was initially mild, associated with morning stiffness that persisted for 1 hour, improved with activities. Pain was progressively increasing in intensity but did not interfere in his daily activities. Pain is not associated with joint swelling. He also complained of non-itchy pink rashes involving chest, abdomen, upper back and a part of neck for last 25 days. Rashes appeared 5 days after development of fever and initially appeared in chest, which then progressed gradually.

On further query, he gave history of getting hospitalized for 2 times back in August, 2015 and October, 2018 with previously mentioned complaints. He was treated with steroid tablets for 4 months on both occasions and improved gradually. He was also given Thyroxine for hypothyroidism. He has a normal dietary habit with normal appetite and no history of food or drug allergy. There was no history of similar illness in his childhood or in any of his family members.

On examination, he was febrile, ill looking with good nutrition and body built. Haemodynamic condition was stable. There were erythematous rashes distributed over chest, abdomen, upper back, shoulders and a part of neck (Figure 2A and 2B). These are of variable sizes, blanchable, non-palpable and non-itchy. Joints

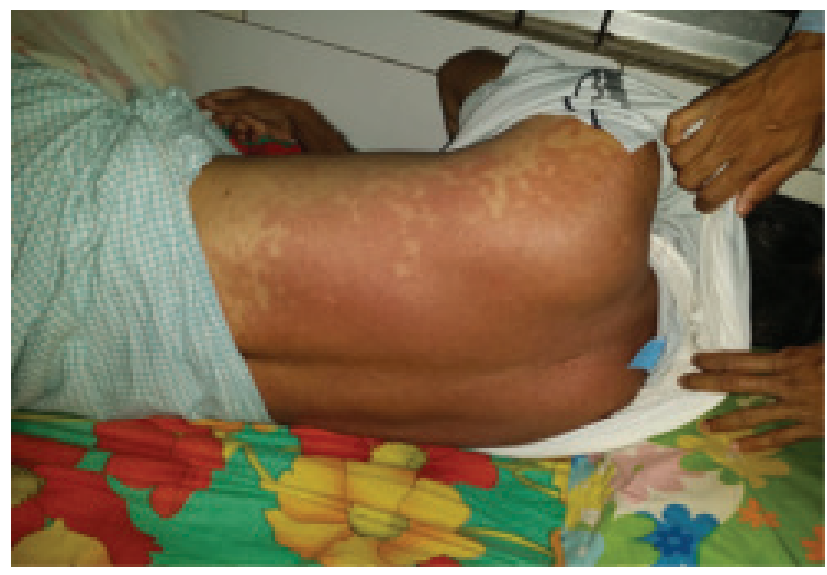

Figure 2B: Blanchable, Non itchy, non palpable pink rashes on back

were mildy tender, not swollen and movement was not restricted with no impairment of the functional status. Local temperature was not raised. There was no wasting of muscles, atrophy, ulcer, infarction, gangrene. Features of peripheral neuropathy in glove and stock pattern were present. There were no lymphadenopathy, thyromegaly or bony tenderness.

Hematological investigations showed mild anamia $(\mathrm{Hb}$ : 10gm/dl); Biochemical investigations showed elevated liver enzymes (alanine transaminase: $102 \mathrm{U} / \mathrm{L}$; aspartate transaminase: $129 \mathrm{U} / \mathrm{L}$ ). Both the acute phase reactants were high with $\mathrm{C}$-reactive protein (24.60 $\mathrm{mg} / \mathrm{L})$ and erythrocyte sedimentation rate (ESR: $69 \mathrm{~mm} / \mathrm{hr}$ ). There were markedly elevated levels of serum ferritin $(1049 \mathrm{ng} / \mathrm{ml}$ on this admission, four years back it was $2363 \mathrm{ng} / \mathrm{ml}$ ). Anti-cyclic citrullinated peptide (Anti CCP), antinuclear antibody (ANA) and rheumatoid factor (RF) were all negative during previous admission, but on this occasion ANA was 400, anti ds DNA was $>240 \mathrm{IU} / \mathrm{ml}$ (positive $>20 \mathrm{IU} / \mathrm{ml}$ ). His serum TSH was $7 \mu \mathrm{IU} / \mathrm{ml}$. Based on his clinical features and review of the laboratory evaluations, he was diagnosed to have AOSD using the Yamaguchi criteria 7 and also SLE according to ARA criteria. He is now being treated with Methotrexate, Hydroxychloroquine, Thyroxine.

\section{Discussion:}

AOSD was first described in 1971 by Eric Bywaters ${ }^{8}$. There is a correlation between several cytokines in the pathogenesis of AOSD, including Tumor necrosis factor-alpha (TNF-á), interleukin (IL)-6 and IL-18. The levels of these cytokines are highly elevated in active $\mathrm{AOSD}^{9}$. Though pathogenesis of the disease remains unclear; however, observations suggesting the role of genetic, infectious and environmental factors have been published 10-12. Typically, patients with AOSD present 
Systemic Lupus Erythematosus) in a male patient previously diagnosed as Adult Onset Still's Disease BJM Vol. 30 No. 2

with rash, fever, sore throat and arthralgia ${ }^{13}$. The typical rash in AOSD is described as salmon-pink, and asymptomatic, maculopapular eruptions mainly affecting the trunk and extremities 14-16. The fever normally exceeds $39.0^{\circ} \mathrm{C}$ and highest temperatures are seen in late afternoon and early evening ${ }^{17}$. Sore throat is one of the major signs of AOSD and may be associated with odynophagia ${ }^{18}$ In our case, sore throat or odynophagia were not present. Though in some study and research papers, Rheumatoid arthritis (RA) were found to be present in association with SLE, in our case we could not find any classical clinical and biochemical features suggestive of RA. Moreover, JIA could also be excluded through meticulous history and age of onset of his symptoms.

The history of lupus has been divided into the classic period of cutaneous description, the neoclassic period that recognized the systemic nature of the disease, and the modern period heralded by the finding of the LE cell ${ }^{19}$. We are now in the "postmodern" lupus period, using techniques of molecular and cellular biology to find underlying themes of immunologic intolerance. Currently, more than 80 percent of the American public has become aware of SLE as an immunologic disease ${ }^{20}$. As mentioned earlier that the etiology of SLE remains unknown and is clearly multifactorial, yet, as with other autoimmune diseases, susceptibility to SLE depends on multiple genes 21,22 .

Abnormalities in sex-hormone metabolism might contribute to gender differences in susceptibility to SLE. Men and women with SLE have accelerated metabolism of testosterone ${ }^{23}$ In terms of antigens bound, it is convenient to think of the autoantibodies of SLE as belonging to one of several groups directed against DNA/protein complexes, RNA/protein complexes, cell membrane structures, and intracellular molecules that reach cell surfaces during cell activation. The antibodies considered to be the hallmark of SLE are IgG antibodies to double-stranded (ds)-DNA.

\section{Conclusion:}

Both SLE and AOSD are very much uncommon disease entity in male, specially after middle age. Some serological markers are quite opposite to each other regarding criteria for the diagnosis. On the other hand, in our case, few crucial clinical and biochemical features were also missing required to fulfill the criteria for Rheumatoid arthritis. So, it was not that straightforward for us to label it as Rhupus (Combination of Rheunmatoid arthritis with SLE), or any of other Overlap syndromes. Proper diagnosis is important in such patient based on regular and frequent measurement of serological markers, so that the criteria of SLE could not be missed. More research study on similar cases would be helpful in furute to reach an immunological basis of pathogenesis for such coexistence of illness.

\section{Reference:}

1. Hahn BH. Systemic Lupus Erythematosus. In: Fauci AS, Braunwald E, Kasper DL, et al, eds. Harrison's Principle of Internal Medicine. New York: McGraw Hill Medical; 2018. p. 2515-26.

2. Eardley KS, Raza K, Adu D, Situnayake RD. Gold treatment, nephrotic syndrome, and multi-organ failure in a patient with adult onset Still's disease. Ann Rheum Dis 2001. Jan;60(1):4-5. 10.1136/ard.60.1.4.https:// doi.org/10.1136/ard.60.1.4 PMid:11114273 PMCid: PMC 1753358

3. Kurasawa M, Kotani K, Kurasawa G, Shida K, Yamada $\mathrm{S}$, Tago T. Adult-onset Still's disease in a patient over 80 years old successfully treated with low-dose methotrexate therapy. Age Ageing2007. Jan;36(1):104106. 10.1093/ageing/afl128.https://doi.org/10.1093/ ageing/afl128. PMid:17158115

4. Lu LJ, Wallace DJ, Ishimori ML, Scofield RH, Weisman MH. Male systemic lupus erythematosus: A review of sex disparities in this disease. Lupus 2010;10:119-29. https://doi.org/ 10.1177 /0961203309350755. PMid:19946032

5. de Carvalho JF, do Nascimento AP, Testagrossa LA, Barros RT, Bonfá E. Male gender results in more severe lupus nephritis. Rheumatol Int 2009;30:1311-5. https:/ /doi.org/10.1007/s00296-009-1151-9.PMid: 19784840

6. Epidemiology and pathogenesis of systemic lupus erythematosus. Windows.uptodate, 2009.

7. Yamaguchi M, Ohta A, Tsunematsu T, Kasukawa R, Mizushima Y, Kashiwagi H, et al. Preliminary criteria for classification of adult Still's disease. J Rheumatol 1992. Mar;19(3):424-430.

8. Bywaters EG. Still's disease in the adult. Ann Rheum Dis 1971. Mar;30(2):121-133. 10.1136/ard.30.2.121 https://doi.org/10.1136/ard.30.2.121.PMid:5315135 PMCid:PMC1005739

9. Chen DY, Lan JL, Lin FJ, Hsieh TY.Proinflammatory cytokine profiles in sera and pathological tissues of patients with active untreated adult onset Still's disease. J Rheumatol 2004. Nov;31(11):2189-2198.

10. Joung CI, Lee HS, Lee SW, Kim CG, Song YH, Jun JB, et al. Association between HLA-DR B1 and clinical features of adult onset Still's disease in Korea. Clin Exp Rheumatol 2003. Jul-Aug;21(4):489-492.

11. Youm JY, Woo JH, Kim TH, Bae SC, Yoo DH. Interleukin-1beta and interleukin-1 receptor antagonist gene polymorphisms in Korean patients with adultonset Still's disease. Scand J Rheumatol 2007. SepOct;36(5):390-393. 10.1080/03009740701340081 
https: / / doi.org/10.1080/03009740701340081. PMid: 17963170

12. Daibata M, Taguchi H. Human herpesvirus 6 and adultonset Still's disease. Am J Med 2002. Oct;113(6):532. 10.1016/S0002-9343(02)01238-X.https://doi.org/ 10.1016/S0002-9343(02)01238-X

13. Larson EB. Adult Still's disease-recognition of a clinical syndrome and recent experience. West J Med 1985. May; 142(5):665-671.

14. Ohta A, Yamaguchi M, Kaneoka H, Nagayoshi T, Hiida M. Adult Still's disease: review of 228 cases from the literature. J Rheumatol 1987. Dec;14(6):1139-1146.

15. Phillips WG, Weller R, Handfield-Jones SE, Kobza-Black A. Adult Still's disease. Br J Dermatol 1994. Apr;130(4):511-513. 10.1111/j.1365-2133.1994. tb03388. x https://doi.org/10.1111/j.1365-2133. 1994. tb03388.x PMid:8186120

16. Ridgway HA. Adult-onset Still's disease. J R Soc Med 1982. Jun;75(6):474-476.

17. Ohta A, Yamaguchi M, Tsunematsu T, Kasukawa R, Mizushima H, Kashiwagi H, et al. Adult Still's disease: a multicenter survey of Japanese patients. J Rheumatol 1990. Aug;17(8):1058-1063

18. Kelly J, Chowienczyk P, Gibson T.Sore throat and hyperferritinaemia. J R Soc Med 2001. Aug;94(8):400401..https://doi.org/10.1177/014107680109400807 .PMid:11461984 PMCid:PMC1281634

19. Hochberg MC: The history of lupus erythematosus. Md Med J 1991; 40:871.

20. Lahita RG: Special report: Adjusted lupus prevalenceResults of a marketing study by the Lupus Foundation of America. Lupus 1995; 4:450.https://doi.org/ 10.1177/096120339500400605 PMid:8749566

21. Tsao BP: An update on genetic studies of systemic lupus erythematosus. Curr Rheumatol Rep 2002; 4(4):359367.https: / /doi.org/10.1007/s1 1926-002-0046-5

22. Harley JB, Moser KL, Gaffney PM, et al: The genetics of human systemic lupus erythematosus. Curr Opin Immunol 1998; 10:690..https://doi.org/10.1016/ S0952-7915(98)80090-3

23. Lahita RG, Kunkel HG, Bradlow HL: Increased oxidation of testosterone in SLE. Arthritis Rheum 1983; 26:1517.https://doi.org/10.1002/art.1780261215 